\title{
Estudio pedagógico sobre el efecto del mes sagrado de Ramadán en el volumen de operaciones y los rendimientos anormales en el mercado de capitales iraní
}

\section{Pedagogical study on the effect of the holy month of Ramadan on the volume of operations and abnormal returns in the Iranian capital market}

\author{
Abdollah Noori ${ }^{1}$, Atallah Mohammadi Molgharni ${ }^{2 a}$, Iraj Noravesh $^{3}$ \\ Islamic Azad University, Sanandaj, Iran ${ }^{123}$ \\ Orcid ID: https://orcid.org/0000-0003-1558-7679 1 \\ Orcid ID: https://orcid.org/0000-0002-9770-3962 2 \\ Orcid ID: https://orcid.org/0000-0002-6157-29803
}

Recibido: 16 de abril de 2020

Aceptado: 12 de octubre de 2020

\begin{abstract}
Resumen
El objetivo de este estudio fue evaluar el efecto calendario del mes sagrado de Ramadán sobre el volumen de operaciones y los rendimientos anormales en el mercado de capitales iraní durante los años 2009 a 2019 durante 10 años en la bolsa de valores. El presente estudio se considera aplicado en términos de propósito y correlación en términos de método descriptivo. Además, se utilizó el modelo de panel de datos para investigar la relación entre las variables. De acuerdo con los resultados, la variable coeficiente del efecto del mes sagrado de Ramadán sobre el volumen de negociación tiene un nivel significativo de 0.441 , por lo tanto, considerando que este valor es mayor que el nivel alfa de la investigación, que es igual a 0.05 , por lo tanto, no se rechaza esta hipótesis (cero) de que la variable del efecto del Ramadán no es efectiva sobre la variable de volumen de comercio. Por tanto, el efecto del calendario del mes sagrado sobre el volumen de transacciones no es significativo. Según los resultados la variable coeficiente del efecto del Ramadán y el retorno de la acción tiene un nivel significativo de 0.000 , por lo que considerando que este valor es menor que el nivel alfa de la investigación, que es igual a 0.05 , por lo tanto, esta hipótesis (cero) que la variable de efecto Ramadán D01 no afecta la rentabilidad de las acciones en Irán, se rechaza.
\end{abstract}

Palabras clave: Mercado de capitales, economía, bolsa, Ramadán, religión iraní

${ }^{\mathrm{a} C}$ Correspondencia al autor:

E-mail: Ataata.mm68@yahoo.com 


\begin{abstract}
The objective of this study was to evaluate the calendar effect of the holy month of Ramadan on trading volume and abnormal returns in the Iranian capital market during the years 2009 to 2019 for 10 years in the stock exchange. The present study is considered as applied in terms of purpose and correlation in terms of descriptive method. Also, the data panel model was used to investigate the relationship between the variables. According to the results, the variable coefficient of the effect of the holy month of Ramadan on the trading volume has a significant level of 0.441, therefore, considering that this value is greater than the alpha level of the research, which is equal to 0.05 , therefore, this hypothesis (zero) that the variable of the effect of Ramadan is not effective on the variable of trading volume, is not rejected. Therefore, the effect of the calendar of the holy month on the volume of transactions is not significant. Also, variable coefficient of the effect of Ramadan and the share return has a significant level of 0.000 , so considering that this value is smaller than the alpha level of the research, which is equal to 0.05 , therefore, this hypothesis (zero) that the variable of Ramadan effect D01 does not affect the share return in Iran, is rejected.
\end{abstract}

Keywords: Capital market, economy, stock exchange, Ramadan, Iranian religion

\title{
Introduction
}

The holy month of Ramadan has a great deal of respect among all Muslims. Ramadan is the month of fasting so, eating and drinking during the day is haram. Restaurants are closed during the day, and not only do people avoid sin and disobedience, but also avoid some common economic activities (Sinai and Mohammadi, 2012). So, most likely, the spiritual atmosphere of this month can reduce investors' use of confidential information in stock trading and reducing its negative consequences. Trading volume is the number of stocks or securities bought and sold in a specific period (Mohammadi, 2016). And to measure the volume of stock exchange transactions in each country, the number of trades made at the end of each day is used, which is expressed by the stock exchange organization of each country (Bialkowski et al., 2009).

The base volume, together with the percentage of allowable price fluctuations per day (compared to the closing price of the previous day), has been set in order to reduce stock price fluctuations. It would be meaningless to set the base volume without considering the percentage of allowable price fluctuations. In financial literature, the impact of special days of the year on different aspects of the securities market is referred to as the Calendar anomaly (Hassan et al., 2019). Some of the factors affecting investor behavior during Ramadan are: Reducing the working hours of banks, banning gambling by Islam, increasing the religious orientation of capital market activists, etc. (Fazel et al., 2005). The reduction of working hours during Ramadan causes economic activity, in general, to decrease to some extent during this month. The trading hours on 
the stock exchange decreases in most Islamic countries during the holy month of Ramadan. Some investors believe that returns during Ramadan are relatively lower than other lunar months (Bialkowski et al, 2009).

Many studies have identified calendar effects on the returns of various stock exchanges around the world, including the effect of January and other months, the effects of holidays, and the effect of a particular day of the week. These effects called calendar anomaly. Many studies have been done on calendar effects in different stock exchanges of the world, but fewer studies have been done in this field in Iran. However, the existence of some features such as the month of Muharram and the month of Ramadan, which are of special importance and respect among Muslims, necessitates such studies. Given the importance of trading volume and abnormal returns in the capital market, the present study investigates the effect of the holy month of Ramadan on trading volume and abnormal returns of the capital market in Iran. In other words, the main question of the present study is whether the effect of the holy month of Ramadan on trading volume and abnormal stock returns in the Iranian capital market is effective or not?

\section{Literature and research background}

\section{The concept of calendar anomaly}

In calendar abnormalities, the time factor affects the capital market. These effects are called calendar effects. From all types of a calendar or seasonal effects, the first day of the week effect (Monday effect) or the of the first month of the year effect (January Effect) can be referred. According to Monday's effect, the stock price is significantly higher than other days of the week, and according to January's effect, the stock price is more than the other months of the year in the first month of January. The lunar calendar of Islamic countries based on Islamic months determines the holidays and special religious ceremonies during the year. Although most Islamic countries use the Gregorian calendar for transactions and working days, the effect of lunar months and days on it, is not ineffective (platonic and Sohrabi, 2015). Each effect of the calendar and none calendar affected differently according to the type of country and economic system governing it (Mohammadi, etc. 2016).

By examining financial markets, especially the stock market, it can be seen that traders are always looking for channels or gaps to increase their profits. Examining the fluctuations of the market index during the days of the week, it is clear that this index shows different fluctuations on 
different days. So, it can be said that these changes are not the same on the first days of the week and the weekend. By observing the historical trend of securities returns or trading volume in specific periods, it is possible to determine the significance of such a pattern for shareholders' decisions or to adjust for index fluctuations. In some researches or scientific studies, the existence or absence of seasonal and calendar patterns such as the end of the year effect, the effect of days of the week, and such like, have been studied at a low level of efficiency (Abdolrahimian and Jamalpur, 2018).

Research shows that this effect has been proven in other advanced markets besides the United States, such as the United Kingdom, France, Canada, Australia, and Japan. The impact of weekdays on stock returns in emerging markets such as Malaysia and Hong Kong have also been examined. Experimental researches show that in most western countries, Mondays are the first day of the stock market with the most negative returns which on Friday, the last trading day of the stock market showed significant positive returns. In some countries, such as Japan, France, Australia, and Singapore, the most negative returns were observed on Tuesdays (Mohammadi, 2016).

\section{The effect of calendar anomaly on the stock market}

There is ample evidence of seasonal patterns or irregularities in financial markets, including the stock market and bonds, over the past half-century. There has been a lot of discussion about these patterns in scientific and experimental circles about their identification, approval, or rejection. According to the efficient-market hypothesis, stock prices in an efficient market always change randomly due to the stock price response to information that is randomly published and offered overtime. Now, if time itself is a factor in changing stock prices; In a way that during a certain period, in addition to the provided information (randomly), time also affects the change of stock prices and changes the nature of random market behavior, such patterns undermine the efficient market hypothesis and takes shape in an irregularity. These effects are called calendar effects or calendar anomaly.

\section{The political rotation effects}

Usually, in the first and the last year of the executive period of a government (president), financial markets experience unusual higher returns than in other years. Therefore, by planning, 
investors adjust their buying and selling time in a timely manner. Lack of stabilization of a government's economic policies in its first year of operation and ambiguity in the executive system of the future government in the last year of a government causes the volatility of financial markets to increase and adjusted returns with a higher risk than other years (Sinaei and Mohammadi, 2012).

Abdolrahimian and Jamalpour (2015) conducted a study entitled "The effect of Ramadan on the Tehran Stock Exchange". The results show that in the lunar months there is a significant relationship between the total market index and trading volume. In the months of Muharram, Safar and Rajab, there is a negative relationship and also the volume of transactions in the months of Muharram, Safar, Rabi al-Awal, and Ramadan has a negative relationship and the rest of the lunar months correlates with the volume of transactions. Salehifar et al. (2017) investigated the effect of Ramadan and Muharram on the risk and efficiency of joint venture funds in Iran's capital market.

The findings show that although some positive and negative relationships are seen in the efficiency and risk of several joint venture funds, it cannot be attributed to all mutual funds as a rule or general behavior. Aflatouni and Sohrabi in a study entitled "The effect of calendar anomaly in religious days on the use of confidential information" to examine the effect of the calendar effect of Ramadan on the possibility of using confidential information in stock transactions between 2008 and 2013 and 112 companies listed in Tehran Securities. The results showed that the probability of using confidential information for stock trading in Muharram is significantly lower than in other months.

However, the possibility of using confidential information during the holy month of Ramadan is not significantly different from other months of the year. Sinaei and Mohammadi (2012) in a study entitled "Analysis of the effect of the holy month of Ramadan on the Tehran Stock Exchange" examined the existence of seasonal patterns in its return and volatility, as well as the number of transactions related to moving calendar events, including the holy month of Ramadan.

\section{Abnormal returns}

Abnormal return is a term used to describe the return on securities over a period of time that differs from the expected rate of return. In fact, abnormal return is the return that results from the difference between the actual return and the expected return (Tong and Zhang, 2015). To calculate the abnormal return on stocks, first, the expected return on the stock is estimated using 
the market model and then the expected return is compared with the actual return to obtain an abnormal return (Mohammadi, 2016).

\section{Volume}

Trading volume is the number of stocks or securities bought and sold in a specific period of time (Mohammadi, 2016). To measure the volume of stock exchange transactions in each country, the number of trades made at the end of each day is used, which is expressed by the stock exchange organization of each country. (Białkowski et al., 2009).

\section{Methodology}

The present study will be conducted in the framework of deductive-inductive reasoning. It is also post-event (semi-empirical), which means it is based on the analysis of past and historical information (corporate financial statements). It is also considered a correlation in terms of applied purpose and descriptive method. The statistical population of the present study is all companies in the pharmaceutical industry listed on the Tehran Stock Exchange, whose shares have been traded on the stock exchange for 8 years from the beginning of 1989 to the end of 1998, and its information should be available. The statistical sample of this research by screening method includes the following: The financial information required to extract the data should be available; the companies under review should not change the fiscal year in the period under review; in the surveyed companies, there should not be any long trading interval for their shares. The data required to calculate the variables related to the stock market were extracted in the first stage using stock software (mainly new revenue and prudence). Then, the general and final figures of this data are matched with the information in the stock exchange trading system.

\section{Research models and variables}

In the present study, to investigate the effect of the holy month of Ramadan on trading volume and abnormal stock returns in the Iranian capital market, the following proposed model, presented by Acharia and Pederson (2018), will be used:

$$
\begin{aligned}
& C P_{i t}=\alpha_{0}+\alpha_{1} D_{R}+a_{2} I N F_{t}+a_{3} E X C H_{t}+a_{4} G D P_{t}+a_{5} G O L D_{t} \\
& A R_{i t}=\alpha_{0}+\alpha_{1} D_{R}+a_{2} I N F_{t}+a_{3} E X C H_{t}+a_{4} G D P_{t}+a_{5} G O L D_{t}
\end{aligned}
$$


The dependent variables: as follows:

$C P_{i t}$ : Trading volume: The final stock price is currently determined using the base volume

A) If the volume of shares traded on a specific day (after deducting major transactions) is less than the volume of the basis for that share, the formula for calculating the final price on this day is as follows:

Close Priceti $=\mathrm{CP}(\mathrm{t}-1) \mathrm{i}+(\mathrm{Vti} / \mathrm{Bi})($ Last Pti $-\mathrm{CP}(\mathrm{t}-1) \mathrm{i})$

The proposed formula for calculating the base volume continues where:

CPt-1: The closing price of share $\mathrm{i}$ on day $\mathrm{t}-1$

Vt: Volume of share i transactions on day $\mathrm{t}$

Bi: Share base volume of $\mathrm{i}$

$A R_{i t}$ : Abnormal stock returns: Like Rasaeian and Ghaffari's research (2012). To calculate the abnormal return on stocks, first, the expected return on the stock is estimated using the market model and then the expected return is compared to the actual return to obtain the abnormal return:

$$
A R_{\mathrm{i}, \mathrm{t}}=\mathrm{E}_{\mathrm{i}, \mathrm{t}}-E(r)_{\mathrm{i}, \mathrm{t}}
$$

$\mathbf{A R}_{\mathbf{i}, \mathbf{t}}$ : Abnormal Return on Stocks i at Time t.

$\mathbf{E}_{\mathbf{i}, \mathbf{t}}$ : Actual Return on Stocks i at t Time.

E(r) $)_{i, t:}$ Expected Return on Stocks i at t Time, based on market model estimates.

\section{Independent variable}

$\left(D_{R}\right)$ : It is the binary variable of the calendar effect of Ramadan, for Ramadan 1 and zero for other months.

\section{Control variables}

$I N F_{t}:$ Includes inflation rate at $\mathrm{t}$ time.

$\mathrm{EXCH}_{t}$ : Exchange rate (official exchange rate of the dollar), at t time.

$G D P_{i}:$ GDP at t time. 
$G O L D_{t}$ : The gold rate at $\mathrm{t}$ time.

\section{Results}

\section{Descriptive statistics of research variables}

As we can see in the table below, for example, the variable (RGOLD) as a variable of the research regression model has an average of 0.029 , mean 0.017 , maximum 0.46 , minimum 0.21 standard deviation 0.087 , skewness 1.22, elongation 7.43, Jarque statistic of 898.53 and the significant probability 0.000 .

Table 1

Table of descriptive indicators and normal test for research variables

\begin{tabular}{ccccccc}
\hline & $\boldsymbol{L C P}_{i t}$ & $\boldsymbol{L I N F _ { i t }}$ & $\boldsymbol{L E X C \boldsymbol { H } _ { i t }}$ & $\boldsymbol{L G O L D}_{i t}$ & $\boldsymbol{A R}_{\boldsymbol{i t}}$ & $\boldsymbol{L G D P}_{i t}$ \\
\hline Average & 13.499 & 2.851 & 0.026 & 0.030 & 0.048 & 3.622 \\
Middle & 13.539 & 2.766 & 0.010 & 0.018 & 0.013 & 3.611 \\
Maxim & 18.697 & 3.754 & 0.477 & 0.461 & 0.780 & 4.143 \\
Minimum & 1.792 & 1.000 & -0.264 & -0.218 & -0.519 & 3.045 \\
$\begin{array}{c}\text { Standard } \\
\text { deviation }\end{array}$ & 2.164 & 0.526 & 0.085 & 0.088 & 0.146 & 0.200 \\
$\begin{array}{c}\text { skewness } \\
\text { Elongation }\end{array}$ & -0.637 & 0.207 & 1.477 & 1.227 & 1.649 & 0.396 \\
$\begin{array}{c}\text { Jarque- } \\
\text { Bera }\end{array}$ & 29.634 & 1.854 & 11.066 & 7.436 & 7.959 & 3.463 \\
$\begin{array}{c}\text { Significant } \\
\text { probability }\end{array}$ & 0.000 & 0.000 & 0.000 & 0.000 & 0.000 & 0.000 \\
\hline
\end{tabular}

\section{Inferential analysis of research data:}

As mentioned before, for inferential analysis of research data performed that has been done with STATA14 EVEIWS10, EXCEL2016 software, first, after reviewing the descriptive properties and, if necessary, normalizing the data to examine the unit root of variables and stabilizing Variables (if required) and after that, the type of research data was used (panel or pooled) to fit the model. Finally, by carefully examining the models, the optimal model will be presented.

As seen in the previous table, the research variables, especially the dependent variable as well as the independent variables, have slight skewness (skewness index indicates the degree of 
data symmetry). Therefore, the data can be considered normal by referring to this issue and also the central limit theorem that in large size societies the distribution of data can be considered normal, so the distribution of data can be considered normal.

\section{Investigating the root of the unit of research variables}

In the table below, this level test is performed for all variables and we see that all variables in terms of the mentioned test have a level of stabilization. Therefore, in the case of using panel data, the license for using level data is approved.

Table 2

Stabilization test results for research variables

\begin{tabular}{ccccc}
\hline Variable & $\begin{array}{c}\text { PP - Fisher Chi- } \\
\text { square }\end{array}$ & p-value & pp-stat & p-value \\
\hline$L I N F_{i t}$ & 36.022 & 0.001 & -3.784 & 0.000 \\
$L G O L D_{i t}$ & 306.749 & 0.000 & -14.370 & 0.000 \\
$L C P_{i t}$ & 317.879 & 0.000 & -13.868 & 0.000 \\
$L G O L D_{i t}$ & 1301.490 & 0.000 & -34.107 & 0.000 \\
$L E X C H_{i t}$ & 1424.880 & 0.000 & -35.838 & 0.000 \\
$A R_{i t}$ & 1496.610 & 0.000 & -36.627 & 0.000 \\
\hline
\end{tabular}

F-Limer test

To analyze the research hypotheses, we first use the F-Limer test to choose between data regression (combined) and regression with fixed effects methods. In estimating the data panel model, we are faced with two general situations. The first case is that the width of the origin is the same for all sections, in which case we are faced with a pool data model. The second case is the width of the origin for all different sections, which is called panel data. A test called F-Limer is used to identify the two above conditions. So, if the significance level of the f test is less than 0.05 , we use the data panel model and if it is greater than 0.05, we use the pool data model. Now, according to the models related to the hypotheses, the results of the F-Limer test for them are given in the table below. 
Table 3

F-Lemmer test

\begin{tabular}{lccc}
\hline Effect test & Test statistics & Freedom degree & $\begin{array}{c}\text { The significance } \\
\text { levels }\end{array}$ \\
\hline $\begin{array}{l}\text { Fixed effects test of } \\
\text { f first model }\end{array}$ & 1.527 & $(6,816)$ & 0.166 \\
$\begin{array}{l}\text { Fixed effect test of } \\
\text { f second model }\end{array}$ & 0.79 & $(7,828)$ & 0.59 \\
\hline
\end{tabular}

Since the significance level of this test is greater than $5 \%$, the data type should be considered pool.

\section{Investigation of variance heterogeneity}

In this test, the null hypothesis implies homogeneity of variances. In this test, if the value obtained for the significance level becomes less than 0.05 , we reject the null hypothesis, meaning the variance homogeneity hypothesis. If the variances are heterogeneous, we should use the EGLS method and if the variances are the same, we should use the OLS method.

\section{Table 4}

Results of variance heterogeneity test

\begin{tabular}{lcc}
\hline & Chi-square statistics & The significance level \\
\hline The first model & 1.083 & 0.189 \\
The second model & 1.137 & 0.177 \\
\hline
\end{tabular}

As we can see in the table above, the value obtained for the significance level of this test is more than 0.05 . So, the variances were the same. Therefore, to fit the regression model, it is better to use the OLS method.

\section{Test of research hypotheses}

As mentioned before, the following model has been used to test this first hypothesis of the research. If the coefficient related to the effect of Ramadan D01 on the trading volume is significant, then the first hypothesis is supported. 


$$
C P_{i t}=\alpha_{0}+\alpha_{1} D_{R}+a_{2} I N F_{t}+a_{3} E X C H_{t}+a_{4} G D P_{t}+a_{5} G O L D_{t}
$$

In the table below, the above model has been fitted.

\section{Table 5}

Fitted regression model to test the first hypothesis

\begin{tabular}{|c|c|c|c|c|}
\hline Variable & $\begin{array}{l}\text { Coefficient } \\
\text { value }\end{array}$ & $\begin{array}{l}\text { The standard } \\
\text { deviation }\end{array}$ & $\begin{array}{l}\text { The statistical } \\
\text { value of } t\end{array}$ & $\begin{array}{l}\text { Significant } \\
\text { probability }\end{array}$ \\
\hline D01 & 0.103 & 0.133 & 0.771 & 0.441 \\
\hline$L I N F_{i t}$ & 1.218 & 0.333 & 3.662 & 0.000 \\
\hline$L E X C H_{i t}$ & 0.811 & 0.791 & 1.025 & 0.305 \\
\hline$L G O L D_{i t}$ & 0.717 & 0.790 & 0.908 & 0.364 \\
\hline$L G O L D_{i t}$ & -0.386 & 0.329 & -1.172 & 0.242 \\
\hline C & 11.437 & 1.618 & 7.068 & 0.000 \\
\hline $\mathrm{AR}(1)$ & 0.744 & 0.024 & 30.674 & 0.000 \\
\hline Square R & 0.609 & \multicolumn{2}{|c|}{$\begin{array}{l}\text { The mean of the dependent } \\
\text { variable }\end{array}$} & 13.502 \\
\hline $\begin{array}{l}\text { Modified square } \\
\mathrm{R}\end{array}$ & 0.603 & \multicolumn{2}{|c|}{$\begin{array}{l}\text { Criterion deviation of the } \\
\text { dependent variable }\end{array}$} & 2.167 \\
\hline Statistical f & 105.888 & \multirow{2}{*}{\multicolumn{2}{|c|}{ Durbin-Watson Statistics }} & 2.392 \\
\hline $\begin{array}{l}\text { Significant } \\
\text { probability of } \\
\text { the whole } \\
\text { model }\end{array}$ & 0.000 & & & \\
\hline
\end{tabular}

According to the table of estimated regression coefficients for the first model of the study, it is observed that the variable coefficient of the effect of the holy month of Ramadan on the trading volume has a significant level of 0.441 . Therefore, considering that this value is greater than the alpha level of the research, which is equal to 0.05 , so the hypothesis (zero) that the variable of Ramadan D01 does not affect the variable of trading volume is not rejected.

Therefore, the calendar effect of the holy month of Ramadan on the volume of transactions is not significant. In evaluating the significance of this model, considering that the significance probability value of $\mathrm{F}$ analysis of variance test is less than 0.05 ( $\mathrm{P}$-value $<0.05$ ), the model is confirmed with $95 \%$ certainty. The model determination coefficient indicates that $60 \%$ of the dependent variable changes are explained by the variables entered in the model. Estimation of Watson and Durbin statistics to confirm the independence of error components shows an estimate 
of this statistic with a value of 2.39 , which is in the appropriate range of 1.5 to 2.5 . The following model was used to test the second hypothesis of the research:

$$
A R_{i t}=\alpha_{0}+\alpha_{1} D_{R}+a_{2} I N F_{t}+a_{3} E X C H_{t}+a_{4} G D P_{t}+a_{5} G O L D_{t}
$$

\section{Table 6}

Fitted regression model to test the second hypothesis

\begin{tabular}{|c|c|c|c|c|}
\hline Variable & $\begin{array}{l}\text { Coefficient } \\
\text { value }\end{array}$ & $\begin{array}{c}\text { The standard } \\
\text { deviation }\end{array}$ & $\begin{array}{l}\text { The statistical } \\
\text { value of } t\end{array}$ & $\begin{array}{l}\text { Significant } \\
\text { probability }\end{array}$ \\
\hline D01 & 0.079 & 0.015 & 5.329 & 0.000 \\
\hline LNINF & 0.068 & 0.010 & 7.164 & 0.000 \\
\hline REXCHNGE & -0.288 & 0.107 & -2.698 & 0.007 \\
\hline RGOLD & 0.156 & 0.104 & 1.508 & 0.132 \\
\hline LNGDP & 0.016 & 0.025 & 0.646 & 0.518 \\
\hline $\mathrm{C}$ & -0.211 & 0.100 & -2.123 & 0.034 \\
\hline Square R & 0.107 & \multicolumn{2}{|c|}{$\begin{array}{c}\text { The mean of the dependent } \\
\text { variable }\end{array}$} & 0.048 \\
\hline $\begin{array}{c}\text { Modified square } \\
\text { R }\end{array}$ & 0.094 & \multicolumn{2}{|c|}{$\begin{array}{l}\text { Criterion deviation of the } \\
\text { dependent variable }\end{array}$} & 0.146 \\
\hline Statistical f & 8.263 & \multirow{2}{*}{\multicolumn{2}{|c|}{ Durbin-Watson Statistics }} & 1.813 \\
\hline $\begin{array}{c}\text { Significant } \\
\text { probability of } \\
\text { the whole } \\
\text { model }\end{array}$ & 0.000 & & & \\
\hline
\end{tabular}

\section{Discussion}

The calendar effect refers to the tendency of stocks to perform differently at different times. This theory states that a particular day of the week, a particular week of the month or even a particular month of the year is more likely to increase or decrease stock prices than other times. The purpose of this study was to evaluate the calendar effect of the holy month of Ramadan on the trading volume and abnormal returns of companies listed on the Tehran Stock Exchange.

The present study is considered as applied in terms of purpose and correlation in terms of descriptive method. According to the results of estimated regression coefficients for the second hypothesis model, it is observed that the variable coefficient of the effect of the holy month of Ramadan and the share return has a significant level of 0.000 therefore, considering that this value is smaller than the alpha level of the research, which is equal to 0.05 therefore, the hypothesis 
(zero) that the effect variable of Ramadan D01 does not affect the share return in Iran is rejected and the opposite hypothesis is supported, so it can be said that there is a significant relationship between the calendar effect of the holy month of Ramadan and the share return in Iran. The results of the research hypothesis are consistent with the results of Aflatuni, (2015) and Bialkowski (2009).

The results showed that the variable coefficient of the effect of the holy month of Ramadan on the trading volume has a significant level of 0.441 , therefore, considering that this value is greater than the alpha level of the research, which is equal to 0.05 therefore, the hypothesis (zero) that the variable of the effect of Ramadan D01 is not affected on the variable of trading volume is not rejected. Therefore, the calendar effect of the holy month of Ramadan on the volume of transactions is not significant. The results of the research hypothesis are consistent with the results of Salehifar, (2017) and Sinai (2012).

The results also showed that there is a significant relationship between the holy month of Ramadan and abnormal stock returns because the probability value $(0.000)$ is $0.05 \%$ less than the standard value. Some of the factors affecting the behavior of investors during Ramadan are: Reducing banks' work hours, the prohibition of gambling and interest by Islam, increasing religious orientation of capital market activists, and so on. In most Islamic countries, the working hours of government offices and departments, as well as the working hours of banks, are reduced. The government also advises the private sector to reduce its working hours. The results of the research hypothesis are consistent with the results of Hassan et al. (2019) and Sinaei and Mohammadi, (2012). According to the results of the policymakers of the Tehran Stock Exchange, they can use the findings of this research to regulate the market mechanism.

\section{Conclusions}

Reducing working hours during Ramadan reduces the overall economic activity during this month to some extent. The trading hours on the stock exchange in most Islamic countries are somewhat reduced during this month. Some investors believe that returns during Ramadan are relatively lower than other lunar months.

Financial markets in Islamic countries around the world experience significant changes in trading activities and the religious orientation of most market participants during the month of Ramadan. Most Islamic countries use both Gregorian and lunar calendars. However, the Hijri solar 
calendar is used in Iran. The Islamic calendar shows most of the religious activities and holidays, while the Gregorian calendar (in Iran, the solar calendar) is used for businesses and government offices.

\section{References}

Aflatuni, A., Ruhollah, M. (2015). The effect of religious calendar anomaly on the use of confidential information in stock trading. Financial Accounting Research, 7(24), 16-1. http://jfak.journals.ikiu.ac.ir/article_908.html

Azwar, R., SonjayaImam, W. (2016). The Ramadan effect: Illusion or reality. Arab Economic and Business Journal, 11(1), 55-71. https://doi.org/10.1016/j.aebj.2016.03.001

Bialkowski, J. P., Etebari, A., Wisniewski, T. P. (2009). Piety and Profits: Stock Market Anomaly during the Muslim Holy Month. Finance and Corporate Governance Conference, 1-49. https://civilica.com/doc/374372/

Hassan, K. (2019). Ramadan effect on stock market return and trade volume: Evidence from Dhaka Stock Exchange (DSE). Financial Economics, 7,45-66. https://doi.org/10.1080/23322039.2019.1605105.

Mohammadi, S. (2016). Study of the effect of moon rotation and market reaction using time-spacefrequency analysis, Case study: Islamic member countries in eight. Master Thesis, Islamic Azad University, Kermanshah Branch, Iran.

Salehifar, M., Hosseini, S. A., and Nilchi, M. (2017). A Study of Ramadan and Muharram on the Risk and Return of Mutual Investment Funds in the Iranian Capital Market. Financial Research, 19(3), 217-238. 10.22059/jfr.2017.212407.1006255

Sinai, H. A., Mohammadi, M. (2012). Analysis of the effect of the holy month of Ramadan on the Tehran Stock Exchange. Islamic-financial research, 2(3), 171-331. $\underline{10.30497 / \text { ifr.2012.1536 }}$ 